TITLE:

\title{
Nitrogen behavior during sludge ozonation: a long-term observation by pilot experiments.
}

$\operatorname{AUTHOR}(S):$

Sui, Pengzhe; Nishimura, Fumitake; Tsuno, Hiroshi

\section{CITATION:}

Sui, Pengzhe ... [et al]. Nitrogen behavior during sludge ozonation: a long-term

observation by pilot experiments.. Water science and technology 2014, 70(2): 289-296

\section{ISSUE DATE:}

2014-02

URL:

http://hdl.handle.net/2433/200622

\section{RIGHT:}

OIWA Publishing 2014. The definitive peer-reviewed and edited version of this article is published in 'Water Science \& Technology Vol 70 No 2 pp 289-296 doi:10.2166/wst.2014.219' and is available at www.iwapublishing.com; This is not the published version. Please cite only the published version.; この論文は出版社版でありません。引用の際には出版社 版をご確認ご利用ください。 


\title{
Nitrogen behavior during sludge ozonation: a long-term observation by pilot experiments
}

\author{
Pengzhe SUI ${ }^{1,2, *}$, Fumitake NISHIMURA ${ }^{1}$, Hiroshi TSUNO ${ }^{1,3}$ \\ ${ }^{1}$ Kyoto University, Kyoto 615-8540, Japan \\ ${ }^{2}$ Tokyo Institute of Technology, Tokyo 152-8552, Japan \\ ${ }^{3}$ Osaka Sangyo University, Osaka 574-8530, Japan \\ * Corresponding author, Email: suipz2005@ gmail.com; \\ Tel: +81-75-3833352; Fax: +81-75-3833351.
}

\section{ABSTRACT}

12

Sludge ozonation is a promising technology for dealing with the increasing challenge of excess sludge treatment and disposal. However, nitrogen behavior during sludge ozonation and subsequent biological removal remains unclear. To clarify the feasibility and stability of oxidizing organic nitrogen (released during sludge ozonation) in the bioreactor (but not during ozonation), and the best operational conditions for sludge ozonation, the nitrogen behavior was investigated by a long-term observation. The results showed that when inlet ozone concentration increased from 30 to $80 \mathrm{mg} \mathrm{O} / \mathrm{L}$ and ozonation time decreased from 29 to $11 \mathrm{~h}$, less soluble organic nitrogen was oxidized to ammonia (from $66.1 \%$ to $18.7 \%$ of soluble total nitrogen). This can reduce the operational costs of sludge ozonation. Furthermore, it is feasible to convert organic nitrogen to nitrate by biological processes because full nitrification was restored in three weeks after shock loading of organic nitrogen owing to the change in ozonation conditions. After combining sludge ozonation with the anaerobic/oxic process, the mass balance for nitrogen showed that nitrogen in the excess sludge decreased with increasing sludge reduction rate. The decreased nitrogen in the excess sludge mainly transformed to nitrogen gas by denitrification, whereas nitrogen in the effluent did not increase obviously.

\section{KEYWORDS}

Sludge ozonation, nitrogen release, nitrogen removal, sludge reduction 


\section{INTRODUCTION}

Excess sludge treatment and disposal has been an increasing challenge with the worldwide application of biological wastewater treatment processes. The increasing amounts of excess sludge and the high cost of its treatment and disposal, which accounts for more than $20 \%$, even up to $60 \%$, of the total plant operating costs (Perez-Elvira et al. 2006; Ginestet 2007; LeBlanc et al. 2008; Foladori et al. 2010), have both necessitated the development of excess sludge reduction technologies. In addition, increasingly stringent regulations regarding sludge treatment and disposal, as well as social and environmental concerns, have resulted in a continuous and considerable impetus for further developments.

Most strategies for sludge reduction are based on lysis-cryptic growth, in which biomass grows using released cell content after sludge disintegration. As one of effective ways to break cells, ozonation of sludge can yield the highest degree of sludge disintegration (Chu et al. 2009). Ozonation for sludge reduction has been proposed since 1990s (Yasui \& Shibata 1994); however, the behavior of inorganic elements during sludge ozonation and their effect on the biological treatment process remain unclear (Sui et al. 2011). Particularly, nitrogen release and the composition of the released soluble nitrogen strongly depend on the operational conditions of sludge ozonation because ozone can further oxidize the released organic nitrogen to ammonia and then to nitrogen oxides (Garcia-Orozco et al. 2011). It has been reported that inorganic nitrogen accounts for approximately $20 \%$ of the released soluble total nitrogen during sludge ozonation for an ozone consumption rate of $100 \mathrm{mg} \mathrm{O}_{3} / \mathrm{g}$ SS (Sui et al. 2011). To minimize costs and effectively utilize ozone, ozone activity should target sludge particles. However, in the complex matrices of activated sludge, sludge particles, released biodegradable organic compounds (including nitrogen element), and other inorganic compounds will compete to react with ozone (Cesbron et al. 2003). Therefore, to save energy and remove nitrogen effectively, it is important to determine the optimum operational conditions for sludge ozonation. The oxidation of organic nitrogen to inorganic nitrogen can occur during sludge ozonation or in a bioreactor. If it occurs during sludge ozonation, the operational costs will increase. If it occurs in the bioreactor, the increased loading rate will probably affect the transformation of nitrogen and its removal rate in anaerobic/oxic $(\mathrm{A} / \mathrm{O})$ or anaerobic/anoxic/oxic $(\mathrm{A} / \mathrm{A} / \mathrm{O})$ processes.

The objectives of the present study are to explore how the oxidation of soluble organic nitrogen can be avoided during ozonation and if the conversion of the released organic nitrogen to ammonia and then nitrate is feasible or brings instability to the subsequent biological steps. We investigated the nitrogen behavior in an advanced sewage treatment process combined with sludge reduction and phosphorus recovery (advanced SRPR process), with a focus on nitrogen release properties during sludge ozonation and subsequent biological removal. Furthermore, we discuss the improved operational mode of sludge ozonation according to the observed behavior of nitrogen compounds during the long-term operation of a pilot-scale experimental system.

\section{MATERIAL AND METHODS}

\section{Experimental Apparatus}

An advanced SRPR process, which incorporated sludge ozonation and phosphorous crystallization into the A/O process (Saktaywin et al. 2005; Saktaywin et al. 2006; Nagare et al. 
2008; Tsuno et al. 2008), was employed in this study. In this process (Figure 1), settled phosphorus-rich supernatant at the end of the anaerobic stage is taken out of the bioreactor for phosphorus recovery, and the excess sludge is treated with ozone and then returned to the bioreactor (Saktaywin et al. 2006).

A pilot-scale experimental system was continuously operated using artificial sewage (Saktaywin et al. 2006; Sui et al. 2011). The system comprises a sequencing batch reactor (SBR) with an effective volume of $100 \mathrm{~L}$ (inner diameter: $40 \mathrm{~cm}$, height: $100 \mathrm{~cm}$ ) for simulating the A/O process, a semibatch mode ozone contact reactor with an effective volume of $6 \mathrm{~L}$ (inner diameter: $10 \mathrm{~cm}$, height: $100 \mathrm{~cm}$ ) for sludge ozonation, and a phosphorus crystallization reactor with an effective volume of $20 \mathrm{~L}$ (inner diameter: $27 \mathrm{~cm}$, cylinder body height: $100 \mathrm{~cm}$, and conical bottom: $45 \mathrm{~cm}$ ) for phosphorus recovery. The continuous operation of the SBR and the phosphorus recovery unit was controlled by timers and water-level controllers. One operational cycle of the SBR was set at $8 \mathrm{~h}$ (Figure S-1) and included the following stages: fill (10 min), anaerobic (110 min, including mixing for $50 \mathrm{~min}$ and settlement for $60 \mathrm{~min}$ when recovering phosphorus), aerobic (4 h), settlement (100 min), and draw and idle (20 min). In each SBR cycle, the phosphorus recovery unit was operated in the sequence of feeding ( $2 \mathrm{~min}$ at the end of the SBR anaerobic stage), reaction (33 $\mathrm{min})$, settlement (50 $\mathrm{min})$, and returning supernatant to the SBR $(1 \mathrm{~h})$. Phosphorus was recovered under the conditions of a molar ratio of $\mathrm{Ca} / \mathrm{P} 3.0$ and $\mathrm{pH}$ 9.0 by adding $\mathrm{CaCl}_{2}$ solution $(10 \mathrm{~g} / \mathrm{L})$ and adjusting the $\mathrm{pH}$ using $\mathrm{NaOH}$ solution $(1 \mathrm{~N})$.

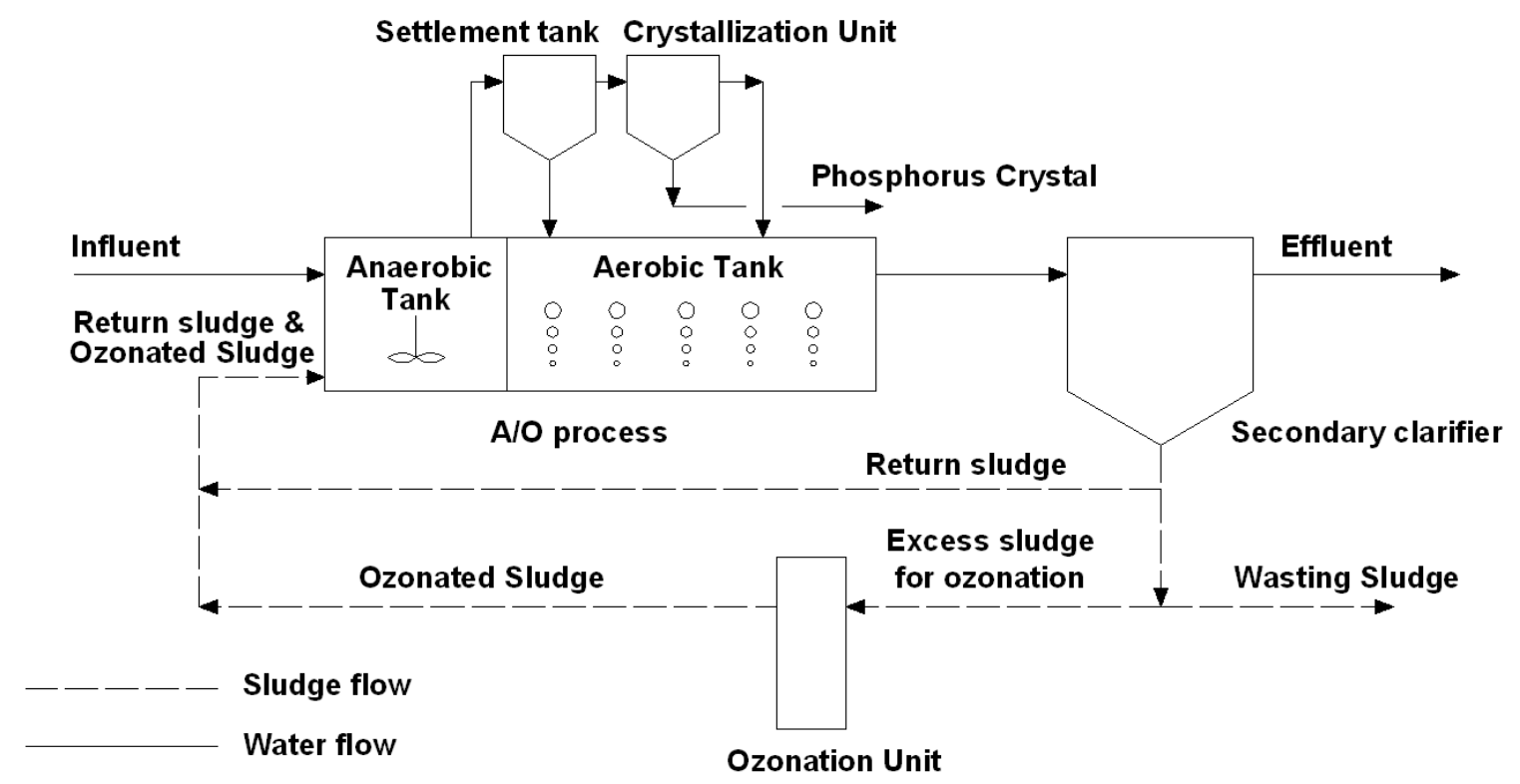

Figure 1 Configuration of the advanced SRPR process

\section{Operational Conditions}

The operation of the pilot-scale advanced SRPR process was divided into three phases, as shown in Table 1. In Phase 1, the system was run as a conventional A/O process without excess sludge reduction (i.e., without sludge ozonation) and phosphorus recovery. In Phases 2 and 3, the system operated as an advanced SRPR process. The excess sludge withdrawn from the SBR was maintained at $2.5 \mathrm{~L} / \mathrm{d}$ in all phases. After withdrawal from the SBR, a portion of the excess sludge was treated by ozone in semibatch mode (continuous flow of ozone gas and batch 
treatment for sludge), and then returned to the SBR together with the influent. The flow rates of the excess sludge for ozonation were $1.5 \mathrm{~L} / \mathrm{d}$ in Phase 2 and $2.1 \mathrm{~L} / \mathrm{d}$ in Phase 3, respectively. Thus, the flow rates of wasted sludge were $1.0 \mathrm{~L} / \mathrm{d}$ in Phase 2 and $0.4 \mathrm{~L} / \mathrm{d}$ in Phase 3, which increased the sludge reduction rate. The ozone consumption rate was set from 80 to $100 \mathrm{mg} \mathrm{O} / \mathrm{g}$ SS for sludge ozonation with sludge decomposition percentage of 20-30\%. The flow rates of the anaerobic supernatant to the phosphorus recovery reactor were 40 and $60 \mathrm{~L} / \mathrm{d}$ in Phase 2 and Phase 3, respectively.

Table 1 Operational conditions for the advanced SRPR process

\begin{tabular}{clccc}
\hline \multicolumn{1}{c}{ Items } & Phase 1 & Phase 2 & Phase 3 \\
\hline 1 & Operational days [d] & 67 & 116 & 97 \\
2 & SBR reactor volume [L] & 100 & 100 & 100 \\
3 & Influent flow rate [L/d] & 225 & 225 & 225 \\
4 & SRT [d] & 10 & 10 & 10 \\
5 & Excess sludge withdrawn [L/d] & 2.5 & 2.5 & 2.5 \\
6 & Ozonated sludge returned to system [L/d] & - & 1.5 & 2.1 \\
7 & Excess sludge wasted [L/d] & 2.5 & 1.0 & 0.4 \\
8 & Ozone consumption rate [mgO $\left.\mathrm{m}_{3} / \mathrm{gSS}\right]$ & - & $80-100$ & $80-100$ \\
9 & Sludge decomposed rate [\%] & - & $20-30$ & $20-30$ \\
10 & Flow rate to P crystallization [L/d] & - & 40 & 60 \\
\hline
\end{tabular}

\section{Analytical Methods}

The sampling frequency was once per week, and samples were taken at the end of each stage (refer to Figure S-1 and Table S-1 for detailed sampling points and schedule) in the cycle from 8:00 to 16:00. After sampling, all soluble samples (Table $S-1$ ) were obtained by immediate filtration through a $1.0 \mu \mathrm{m}$ glass filter (Whatman ${ }^{\circledR}$ GF/B 1821-47, England). The analytical items included total nitrogen (TN) in non-filtered ozonated sludge and effluent, soluble total nitrogen (S-TN), ammonia (NH4), nitrite (NO2), nitrate (NO3), and total organic carbon (TOC) in filtered supernatant and effluent, suspended solid (SS) in effluent, and mixed liquid suspended solid (MLSS) in reactor. All analytical methods were based on Standard Methods (APHA et al. 2005). Nitrogen oxides (NOx, sum of NO2 and NO3), soluble organic nitrogen (Org-N, S-TN minus NH4 and NOx), and particulate total nitrogen (P-TN, TN minus S-TN) were calculated from the measured concentrations of nitrogen species.

\section{RESULTS AND DISCUSSION}

\section{Nitrogen Release during Sludge Ozonation}

Excess sludge, discharged from the bioreactor, was treated with ozone. Along with particulate sludge decomposition, nitrogen was released from the cells to the bulk liquid together with organic carbon. The variations of the different nitrogen species in the ozonated sludge, which was returned to the bioreactor together with the influent, are shown in Figure 2. For ozone consumption rates of 80-100 $\mathrm{mg} \mathrm{O}_{3} / \mathrm{g} \mathrm{SS}$, approximately $35 \%$ of the particulate nitrogen in the sludge was released as soluble components (S-TN). The ratio of S-TN/TN in the ozonated sludge averaged $34.5 \%$ in Phase 2 and 35.6\% in Phase 3. The S-TN composition, i.e., percentages of soluble organic nitrogen, nitrogen oxides, and ammonia, is shown in Figure $2 \mathrm{~b}$. NOx was no more than $2 \%$ of S-TN in most cases. Org-N averaged $70.7 \%$ and $82.2 \%$, whereas ammonia averaged $28.0 \%$ and $16.2 \%$ in Phases 2 and 3, respectively. 


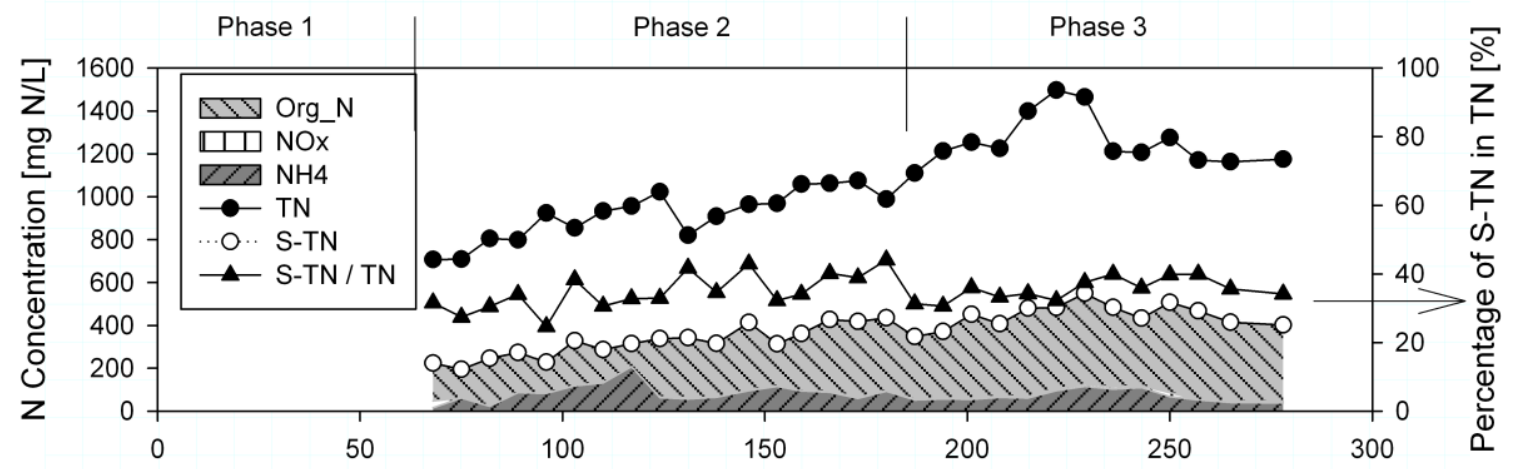

(a)

Days [d]

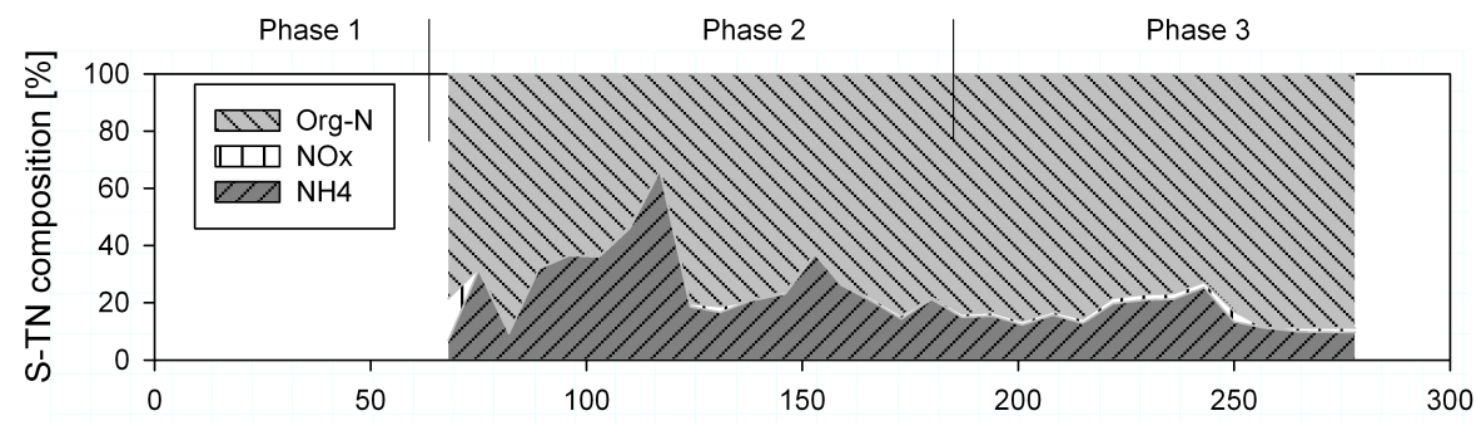

(b)

131

132

133

134

135

136

137

138

139

140

141

142

143

144

145

146

147

148

149

150

151

152

Days [d]

Figure 2 Nitrogen species in the ozonated sludge.

(a) Concentration of each nitrogen species; (b) Percentage of each nitrogen species in S-TN Note: No data for phase 1 because it's run as the conventional $A / O$ process and no sludge ozonation was combined; Org-N: organic nitrogen; NOx: nitrogen oxides; NH4: ammonia; TN: total nitrogen; S-TN: soluble total nitrogen

Along with sludge reduction, mixed liquor suspended solids in the bioreactor increased incrementally (Figure S-2). To maintain the same ozone consumption rate (80-100 $\mathrm{mg} \mathrm{O}_{3} / \mathrm{g} \mathrm{SS}$ ), and therefore the same sludge decomposition rate (20\%-30\%), the reaction time of the sludge ozonation increased under the same inlet ozone concentration. It was found that the ammonia concentration in the ozonated sludge increased gradually in Phase 2 (68-117 days in Figure 2a). To reduce the total reaction time of the sludge ozonation, the inlet ozone concentration was increased from 30 to $80 \mathrm{mg} \mathrm{O} / \mathrm{L}$ on the $124^{\text {th }}$ day. The reaction time of the sludge ozonation decreased from $29 \mathrm{~h}$ to $11 \mathrm{~h}$, approximately. It was found that S-TN in the ozonated sludge remained at the same level (approximately $330 \mathrm{mg}$ N/L) because the sludge decomposition rate did not change under the same ozone consumption rate. However, the S-TN composition in the ozonated sludge changed sharply. The ammonia concentration decreased from $207 \mathrm{mg} \mathrm{N} / \mathrm{L}(66.1 \%$ of S-TN) to $63 \mathrm{mg} \mathrm{N} / \mathrm{L}(18.7 \%$ of S-TN), whereas the Org-N increased from $105 \mathrm{mg}$ N/L (33.7\% of S-TN) to $271 \mathrm{mg} \mathrm{N} / \mathrm{L}(80.3 \%$ of S-TN). The results suggest that the composition of the released nitrogen was affected by the inlet ozone concentration and reaction time. For the same ozone consumption rate, the lower inlet ozone concentration and longer ozonation time contributed to the oxidation of more organic nitrogen to ammonia. 
It was well documented that raw excess sludge decomposed to suspended micro particles, then oxidized to soluble COD, and finally mineralized to carbon dioxide gradually during sludge ozonation (Chu et al. 2009). However, for the transformation of nitrogen, most researchers have reported that organic nitrogen was the main oxidation product during sludge ozonation (Zhao et al. 2007; Naso et al. 2008); further oxidation to ammonia has seldom been reported. Cesbron et al. (2003) investigated the competition for ozone between the soluble compounds and solid particles and corresponding chemical reaction rates. Nishijima et al. (2003) concluded that longterm ozonation was not effective in producing biodegradable organic forms because most of the ozone was used to oxidize the biodegradable products generated in the early stage of ozonation. Similar to the oxidation of organic carbon, the results in this study suggest that organic nitrogen does not always increase and may oxidize to ammonia. Under the condition of the same total ozone consumption rate, the lower ozone inlet concentration and longer ozonation time contributed to the oxidation of more organic nitrogen to ammonia. This should be avoided to reduce the operational costs of sludge ozonation because the oxidation of organic nitrogen to ammonia by ozone gas is much more costly than oxidation in the subsequent biological treatment process. The above results were derived solely from the observations of long-term operation of the advanced SRPR process. More detailed studies are required to determine the chemical reaction rates between nitrogen compounds and ozone, as well as the effects of physical mixing and bubble size.

\section{Nitrogen Removal by Biological Process}

Higher ozone inlet concentration and shorter ozonation time result in organic nitrogen release mainly during sludge ozonation. However, it is moot whether such released organic nitrogen can be effectively and steadily removed in the A/O process. As shown in Figure 3a, the average S$\mathrm{TN}$ in the effluent ranged from 7.5 to $8.5 \mathrm{mg} \mathrm{N} / \mathrm{L}$ in each phase. Among nitrogen species, the average Org-N concentration in the effluent (Figure 3b) increased from $0.54 \mathrm{mg}$ N/L (7.3\% of STN) in Phase 1 to $0.78 \mathrm{mg} \mathrm{N} / \mathrm{L}$ (9.2\% of S-TN) in Phase 2, and $1.0 \mathrm{mg} \mathrm{N} / \mathrm{L}(12.7 \%$ of S-TN) in Phase 3. The average total organic carbon (TOC) in the effluent was found to increase from 3.3 $\mathrm{mg} \mathrm{C} / \mathrm{L}$ in Phase 1 to $7.9 \mathrm{mg} \mathrm{C/L}$ in Phase 2 and $10.4 \mathrm{mg} \mathrm{C} / \mathrm{L}$ in Phase 3 (Figure 3b). It has been reported that soluble organic carbon in the effluent increased because of the non-biodegradable fraction from sludge ozonation (Chu et al. 2009). For ozone consumption rates of $30-40 \mathrm{mg} \mathrm{O}_{3} / \mathrm{g}$ $\mathrm{SS}, 25 \%$ of the soluble organic in the ozonated sludge was found to be refractory matter (Saktaywin 2005). Refractory organic matter during sludge ozonation originated from the disintegration of activated sludge and mainly consisted of proteins and sugar moieties (Dignac et al. 2000). However, there are few reports in the literature for increasing organic nitrogen in the effluent. The increase in organic nitrogen in the effluent was attributed to with the same mechanism as the increase in refractory organic carbon. Nitrogen in amide groups generated by sludge ozonation was refractory to the treatment (Dignac et al. 2000).

Almost all inorganic nitrogen in the effluent was nitrate nitrogen (Figure 3a), which suggest good nitrification. However, an unusually high level of ammonia was detected in the effluent (10.8 $\mathrm{mgN} / \mathrm{L}$, full nitrification was not obtained), which coincided with the change in operational conditions of sludge ozonation on the $124^{\text {th }}$ day. The boxplots in Figure $3 \mathrm{c}$ show three outliers for ammonia (more than $0.1 \mathrm{mg} \mathrm{N} / \mathrm{L}$ ) in the observations. According to the measured Org-N and NH4 in the ozonated sludge (as shown above) and influent $(2.65 \mathrm{~g} \mathrm{~N} / \mathrm{d}$ for NH4 and $1.85 \mathrm{~g} \mathrm{~N} / \mathrm{d}$ for Org-N) as well as mixed liquor volatile suspended solids (MLVSS, $3.18 \mathrm{mg} / \mathrm{L}$ on the $124^{\text {th }}$ 
day), Org-N loading increased from 2.81 to $3.16 \mathrm{mg} \mathrm{N} / \mathrm{g}$ VSS (12.4\%) while NH4 decreased from 4.14 to $3.84 \mathrm{mg} \mathrm{N} / \mathrm{g}$ VSS (-7.3\%). This shock loading of nitrogen was assumed responsible for the failure of full nitrification. However, after only three weeks, the expected performance of the advanced SRPR process was re-established and full nitrification was restored. The rapid restoration of nitrification suggests that biological treatment is adaptive and capable of converting Org-N to nitrate; moreover, avoiding conversion during sludge ozonation is feasible.
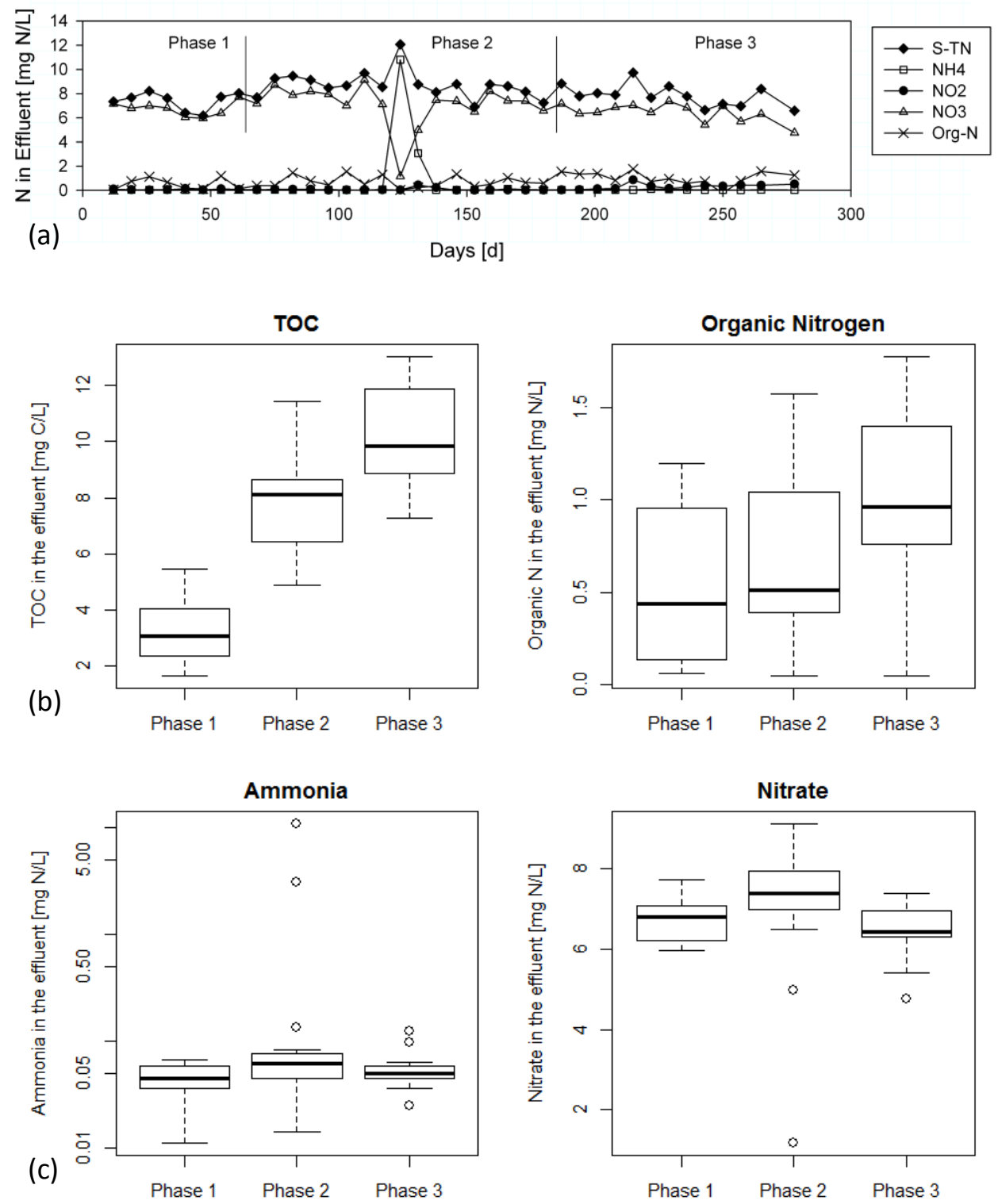

Figure 3 (a) Concentration of nitrogen species in the effluent;

(b) Boxplot of TOC and organic nitrogen in the effluent in each operational phase;

(c) Boxplot of ammonia and nitrate in the effluent in each operational phase. 


\section{Mass Balance of Nitrogen in the Advanced SRPR Process}

The mass balance of nitrogen in the advanced SRPR process is shown in Figure 4. Because ozonated sludge was cycled back to the bioreactor internally, the nitrogen inflow to the system was influent only, whereas the outflow included nitrogen discharged by the excess sludge, nitrogen in the effluent, nitrogen precipitated in the phosphorus crystallization (P-cry) reactor and nitrogen removed by denitrification $\left(\mathrm{N}_{2}\right)$. On the basis of the experimental results, the particulate nitrogen in the wasted excess sludge, the effluent, and the loss in the P-cry reactor were calculated by the corresponding SS concentrations and measured nitrogen contents in SS (mg P-TN/g SS). The soluble nitrogen in effluent came from S-TN measurements.
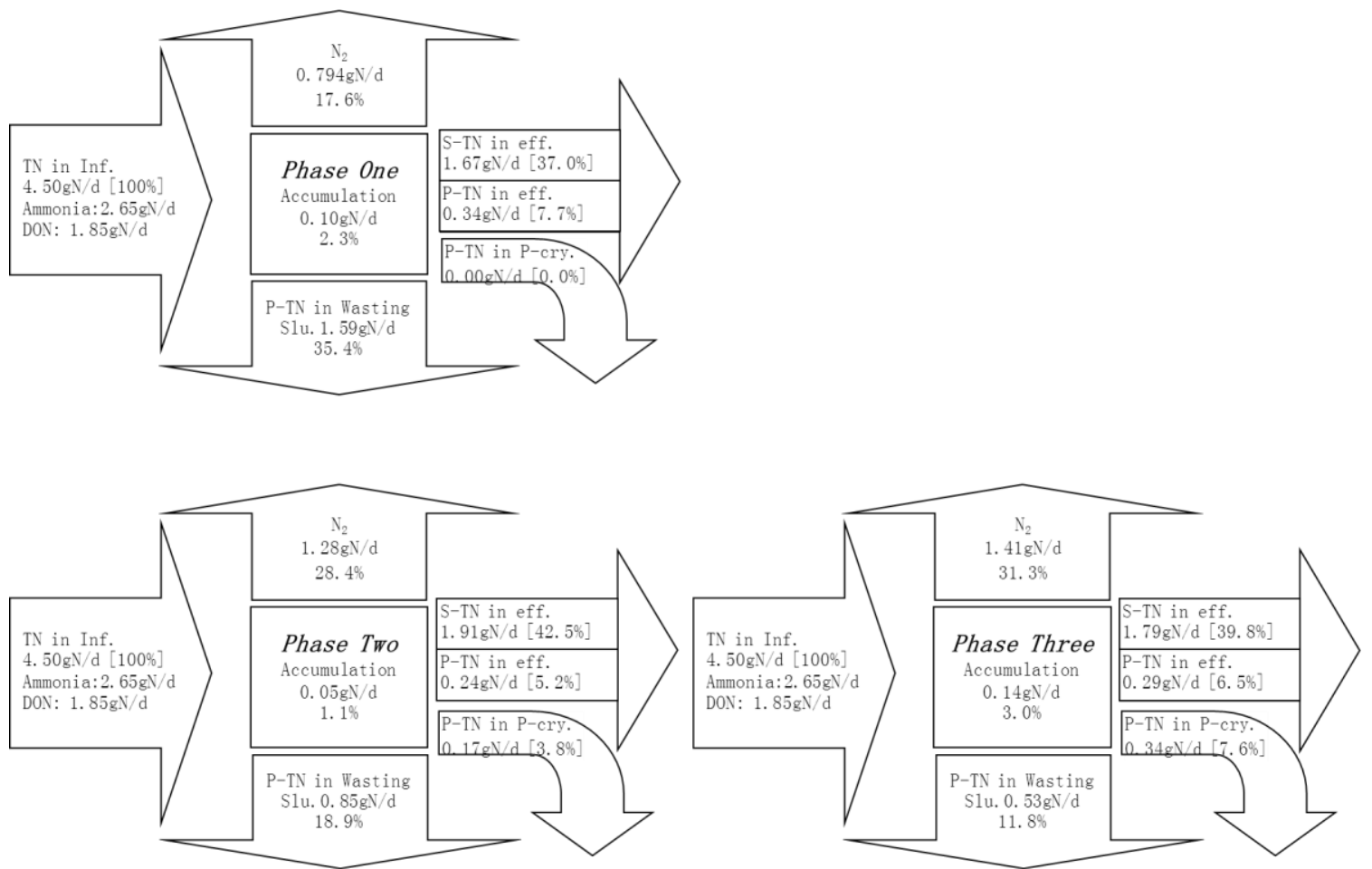

Figure 4 Mass balance for nitrogen in the advanced SRPR process.

(TN: total nitrogen; DON: dissolved organic nitrogen; P-TN: particulate total nitrogen; S-TN: soluble total nitrogen; P-cry: Phosphorus crystallization unit; Inf.: influent; eff.: effluent)

According to the mass balance calculations for nitrogen, the particulate nitrogen in wasted sludge decreased from 35.4\% in Phase 1 to 18.9\% in Phase 2 and $11.8 \%$ in Phase 3, corresponding to the increasing reduction rate of excess sludge. Nitrogen gas generated by denitrification increased from $17.6 \%$ in Phase 1 to $28.4 \%$ in Phase 2 and $31.3 \%$ in Phase 3, which indicated the increase in nitrogen removal. TN in the effluent accounted for $44.7 \%, 47.7 \%$, and $46.3 \%$ in the three operational phases, respectively. The results indicated that the nitrogen in the effluent did not clearly increase with increasing reduction rate of excess sludge. The reduced nitrogen in the excess sludge mainly transformed to nitrogen gas by denitrification after combined $\mathrm{A} / \mathrm{O}$ process with sludge ozonation.

By sludge ozonation, organic carbon and nitrogen were released from the biomass owing to sludge disintegration. The released organic carbon was probably reused by microorganisms and a 
fraction of the organic carbon transformed to carbon dioxide. With the same mechanisms, the released nitrogen from the biomass could also be oxidized from organic nitrogen or ammonia to nitrates. From this perspective, the combined biological process with sludge ozonation has a high nitrogen removal potential. Furthermore, denitrification is often limited by the carbon source in an actual sewage treatment plant; it has been proven that organics released from sludge ozonation can serve as the carbon source for denitrification (Ahn et al. 2002; Cui \& Jahng 2004; Dytczak et al. 2007). It has been reported that the denitrification rate improved up to $20 \%$ because of the additional carbon release by ozonation at an ozone dosage of $0.08 \mathrm{~g} \mathrm{O}_{3} / \mathrm{g}$ TSS (Dytczak et al. 2007), which is consistent with the results obtained in this study.

\section{CONCLUSIONS}

Nitrogen behavior during sludge ozonation and subsequent biological removal was examined via observations of long-term operation of a lab-scale experimental system. The main conclusions are as follows:

1. For ozone consumption rates of $80-100 \mathrm{mg} \mathrm{O}_{3} / \mathrm{g} \mathrm{SS}, 35 \%$ particulate nitrogen was released as the soluble components. Nitrogen release during sludge ozonation strongly depended on the operational conditions. At the same ozone consumption rate, the lower inlet ozone concentration and longer ozonation time contributed to the oxidation of more soluble organic nitrogen to ammonia. This should be avoided to reduce the operational costs of sludge ozonation.

2. Full nitrification was restored in three weeks after the shock loading of nitrogen, caused by the change in operational conditions during sludge ozonation. The rapid restoration of nitrification suggests that biological treatment is adaptive and capable of converting Org-N to nitrate; furthermore, avoiding conversion during sludge ozonation is feasible.

3. Assuming the same mechanisms as the increase in refractory organic carbon, soluble organic nitrogen in the effluent was found to increase owing to sludge ozonation.

4. After combining the $\mathrm{A} / \mathrm{O}$ process with sludge ozonation, the mass balance for nitrogen showed that nitrogen in excess sludge decreased with increasing sludge reduction rate. Nitrogen removal by denitrification clearly increased, whereas nitrogen in the effluent did not clearly increase. The reduced nitrogen in excess sludge mainly transformed to nitrogen gas by denitrification.

Based on above findings, it's concluded that combination of sludge ozonation into $\mathrm{A} / \mathrm{O}$ or $\mathrm{A} / \mathrm{A} / \mathrm{O}$ process is a feasible and promising technology for sludge reduction and nitrogen removal simultaneously.

\section{ACKNOWLEDGEMENTS}

This research was partly supported by grant funding from Steel Foundation for Environmental Protection Technology in Japan (10_11_12 Water quality-327). 


\section{REFERENCES}

Ahn K. H., Park K. Y., Maeng S. K., Hwang J. H., Lee J. W., Song K. G. and Choi S. (2002). Ozonation of wastewater sludge for reduction and recycling. Water Science and Technology 46(10), 71-7.

APHA, AWWA and WEF (2005). Standard Methods for the Examination of Water \& Wastewater. American Public Health Association, Washington, DC.

Cesbron D., Deleris S., Debellefontaine H., Roustan M. and Paul E. (2003). Study of competition for ozone between soluble and particulate matter during activated sludge ozonation. Chemical Engineering Research \& Design 81(A9), 1165-70.

Chu L. B., Yan S. T., Xing X. H., Sun X. L. and Jurcik B. (2009). Progress and perspectives of sludge ozonation as a powerful pretreatment method for minimization of excess sludge production. Water Research 43(7), 1811-22.

Cui R. and Jahng D. (2004). Nitrogen control in AO process with recirculation of solubilized excess sludge. Water Research 38(5), 1159-72.

Dignac M. F., Derenne S., Ginestet P., Bruchet A., Knicker H. and Largeau C. (2000). Determination of structure and origin of refractory organic matter in bio-epurated wastewater via spectroscopic methods. Comparison of conventional and ozonation treatments. Environmental Science \& Technology 34(16), 3389-94.

Dytczak M. A., Londry K. L., Siegrist H. and Oleszkiewicz J. A. (2007). Ozonation reduces sludge production and improves denitrification. Water Research 41(3), 543-50.

Foladori P., Andreottola G. and Ziglio G. (2010). Sludge reduction technologies in wastewater treatment plants. IWA Publishing, London, UK.

Garcia-Orozco J. H., Vargas-Martinez A. and Ayala-Arnez M. A. (2011). Pre-ozonation in the activated sludge process: fate of nitrogen species. Water Science and Technology 63(11), 2513-9.

Ginestet P. (2007). Comparative evaluation of sludge reduction routes. IWA Publishing, London, UK.

LeBlanc R. J., Matthews P. and Richard R. P. (2008). Global atlas of excreta, wastewater sludge, and biosolids management: moving forward the sustainable and welcome uses of a global resource, United Nations Human Settlements Programme (UN-HABITAT), UNHABITAT, Nairobi, Kenya.

Nagare H., Tsuno H., Saktaywin W. and Soyama T. (2008). Sludge ozonation and its application to a new advanced wastewater treatment process with sludge disintegration. OzoneScience \& Engineering 30(2), 136-44.

Naso M., Chiavola A. and Rolle E. (2008). Application of excess activated sludge ozonation in an SBR plant. Effects on substrate fractioning and solids production. Water Science and Technology 58(1), 239-45.

Nishijima W., Fahmi, Mukaidani T. and Okada M. (2003). DOC removal by multi-stage ozonation-biological treatment. Water Research 37(1), 150-4.

Perez-Elvira S. I., Nieto Diez P. and Fdz-Polanco F. (2006). Sludge minimisation technologies. Reviews in Environmental Science and Bio/Technology 5(4), 375-98.

Saktaywin W. (2005). Development of advanced sewage treatment process with excess sludge reduction and phosphorus recovery. Ph.D. Dissertation, the Department of Urban and Environmental Engineering, Kyoto University, Kyoto. 
314 Saktaywin W., Tsuno H., Nagare H., Soyama T. and Weerapakkaroon J. (2005). Advanced 315 sewage treatment process with excess sludge reduction and phosphorus recovery. Water 316 Research 39(5), 902-10.

318

Saktaywin W., Tsuno H., Nagare H. and Soyarna T. (2006). Operation of a new sewage treatment process with technologies of excess sludge reduction and phosphorus recovery. Water Science and Technology 53(12), 217-27.

Sui P., Nishimura F., Nagare H., Hidaka T., Nakagawa Y. and Tsuno H. (2011). Behavior of inorganic elements during sludge ozonation and their effects on sludge solubilization. Water Research 45(5), 2029-37.

Tsuno H., Arakawa K., Kato Y. and Nagare H. (2008). Advanced sewage treatment with ozone under excess sludge reduction, disinfection and removal of EDCs. Ozone-Science \& Engineering 30(3), 238-45.

Yasui H. and Shibata M. (1994). An Innovative Approach to Reduce Excess Sludge Production in the Activated-Sludge Process. Water Science and Technology 30(9), 11-20.

Zhao Y. X., Yin J., Yu H. L., Han N. and Tian F. J. (2007). Observations on ozone treatment of excess sludge. Water Science and Technology 56(9), 167-75. 